\title{
Interactions between beef salt-solu- ble proteins and elephant foot yam (Amorphophallus campanulatus) flour in heat-induced gel matrix development
}

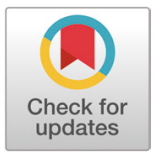

Received: Nov 11, 2019

Revised: Apr 6, 2020

Accepted: Jun 3, 2020

*Corresponding author

Djalal Rosyidi

Faculty of Animal Science,

Universitas Brawijaya, Malang 65145,

Indonesia.

Tel: +62-341-553513

E-mail: djalal_tht@ub.ac.id

Copyright $\odot 2020$ Korean Society of Animal Sciences and Technology.

This is an Open Access article distributed under the terms of the Creative Commons Attribution Non-Commercial License (http:// creativecommons.org/licenses/by$\mathrm{nc} / 4.0 /$ ) which permits unrestricted non-commercial use, distribution, and reproduction in any medium, provided the original work is properly cited.

ORCID

Eny Sri Widyastuti

https://orcid.org/0000-0001-8605-7873 Djalal Rosyidi

https://orcid.org/0000-0002-7359-2356

Lilik Eka Radiati

https://orcid.org/0000-0002-3289-6804

Purwadi Purwadi

https://orcid.org/0000-0003-0309-4113

Competing interests

No potential conflict of interest relevant to this article was reported.

Funding sources

This study was supported by Beasiswa

Pendidikan Pascasarjana program

from Directorate General of Higher

\author{
Eny Sri Widyastuti', Djalal Rosyidii, ${ }^{2 *}$ Lilik Eka Radiati ${ }^{2}$ and Purwadi Purwadi ${ }^{2}$ \\ ${ }^{1}$ Doctoral Program, Faculty of Animal Science, Universitas Brawijaya, Malang 65145, Indonesia \\ ${ }^{2}$ Faculty of Animal Science, Universitas Brawijaya, Malang 65145, Indonesia
}

\begin{abstract}
The objective of this study was to observe the interactions between salt-soluble proteins extracted from beef and elephant foot yam (Amorphophallus campanulatus) flour in heat-induced gel matrix development. The effect of salt concentration; $0.5 \%, 1.0 \%, 1.5 \%$, and $2.0 \%$ in weight/weight basis $(\mathrm{w} / \mathrm{w})$, during protein extraction on $\mathrm{pH}$, salt-soluble protein concentration and myofibril fractions of beef extract was determined firstly, and no significant effect was found. The beef salt-soluble proteins extracted using salt solution at different concentrations were then added with elephant foot yam flour at $5 \%, 10 \%$, and $15 \% \mathrm{w} / \mathrm{w}$, gelatinized at $90^{\circ} \mathrm{C}$ for $20 \mathrm{~min}$, and cooled down at $4^{\circ} \mathrm{C}$ for $12 \mathrm{~h}$. The interactions between beef salt-soluble proteins and elephant foot yam flour resulted in an improved gel strength $(p<0.01)$ and the addition level of elephant foot yam flour affected the $\mathrm{pH}$, instrumental color, moisture, crude protein, and ash content significantly. The addition of elephant foot yam flour also reduced the size of the pores in the gel matrix as shown by scanning electron microscope (SEM) photographs. These suggest that elephant foot yam flour well interacts with beef salt-soluble proteins to form gel matrix.

Keywords: Elephant foot yam, Gelatinization, Gel strength, Microstructure, Myofibrillar protein
\end{abstract}

\section{INTRODUCTION}

Myofibrillar proteins play a significant role in the development of gel matrix in meat emulsion products and have functionality as water and fat binder in restructured meat products [1]. Before emulsification, the water and fat molecules in the mixture or batter of restructured meat are not well homogenized. After emulsification and during heat-induced gelatinization, myofibrillar proteins develop matrix to bound water and fat molecules to form uniform and consistent gel [2]. In order to optimizing the development of emulsion gel, myofibrillar proteins should be extracted from the meat structure [3]. Myofibrillar proteins comprise of approximately $45 \%$ myosin group and 25\% actin group and build approximately $50 \%$ to $60 \%$ of meat proteins. Myosin and actin, the major meat proteins, are salt-solu- 
Education of the Republic of Indonesia (DIKTI) and Faculty of Animal Science, Universitas Brawijaya.

\section{Acknowledgements}

The authors would like to thank Directorate General of Higher Education of the Republic of Indonesia (DIKTI) for Beasiswa Pendidikan Pascasarjana and Faculty of Animal Science, Universitas Brawijaya for financial support.

Availability of data and material Not applicable.

Authors' contributions

Conceptualization: Widyastuti ES, Rosyidi D, Radiati LE, Purwadi P.

Data curation: Widyastuti ES.

Formal analysis: Widyastuti ES.

Methodology: Widyastuti ES.

Software: Widyastuti ES.

Validation: Rosyidi D.

Investigation: Radiati LE, Purwadi P.

Writing - original draft: Widyastuti ES.

Writing - review \& editing: Widyastuti ES, Rosyidi D, Radiati LE, Purwadi P.

Ethics approval and consent to participate This article does not require IRB/IACUC approval because there are no human and animal participants. ble and can retain water in the matrix of meat emulsion gel [4]. When heat is added, myofibrillar proteins are being partially denatured followed by irreversible aggregation, and eventually resulting a 3-dimensional gel matrix [5,6]. The $\mathrm{pH}$ and ionic strength of the solution used for myofibrillar protein extraction influence the extractability significantly. The optimum $\mathrm{pH}$ to extract myofibrillar proteins from meat structure is approximately 6.5 to 7.0 and the ionic strength should be more than $0.3 \mathrm{M}[3,6]$. Further, the solubility of myofibrillar protein in emulsion system will optimize the interactions between protein, fat, moisture and carbohydrate found in the emulsion system to form uniform emulsion gel matrix [7].

Elephant foot yam (Amorphophallus campanulatus) is a plant that is relatively close to konjac (Amorpphophallus oncophyllus). The tuber roots of these plants are rich in starch, cellulose and dietary fibers. However, they contain poisonous crystal calcium oxalate that should be remove prior to consumption. Soaking in salt solution followed by heat treatment can eliminate crystal calcium oxalate from elephant foot yam, but further processes, e.g. using enzyme, should be performed to remove crystal calcium oxalate and optimize the extraction of glucomannan from konjac [8]. The flour of elephant foot yam can be utilized as binder, extender or filler in emulsion-type food as it contains glucomannan $[9,10]$. The starch and glucomannan from elephant foot yam will develop a firm gel when water and heat are added [11]. Therefore, elephant foot yam flour has a potency to be used as binder in meat emulsion products.

Starch and glucomannan from elephant foot yam may have a functionality to develop a good meat emulsion gel. Liu et al. [12] reported that the hydroxyl group in konjac oligo-glucomannan are abundant and can improve the functionality of meat products. Restructured meat products are made from ground meat, added with other ingredients that have function as emulsifier, binder, extender, and flavor enhancer. In the process of texture development, an ingredient that can absorb and retain moisture is important to be added in meat emulsion to prevent syneresis. Many studies have been reported that the utilization of konjac glucomannan, carrageenan, and alginate in meat products can enhance the acceptability of the products as those ingredients can improve texture [13-15]. There is limited information regarding the utilization of elephant foot yam flour in meat products. Therefore, the objective of this study was to observe the interactions between beef salt-soluble proteins extracted using salt solution at different concentrations and elephant foot yam flour in the development of gel matrix.

\section{MATERIALS AND METHODS}

\section{Materials}

The fresh beef from round cut was purchased $5 \mathrm{~h}$ post slaughter and stored at $-20^{\circ} \mathrm{C}$ for $24 \mathrm{~h}$. The frozen meat was thawed at $4^{\circ} \mathrm{C}$ overnight, trimmed of excess fat and visible connective tissue, ground through 6-mm plate grinder and stored at $4{ }^{\circ} \mathrm{C}$ for $12 \mathrm{~h}$. To prepare elephant foot yam flour, a method described by Faridah [16] was used. The skin of elephant foot yam was peeled, the peeled yam was washed twice in flowing water and sliced into 2-3 $\mathrm{mm}$ thick. The chips were soaked in salt solution $(5 \% \mathrm{NaCl}$ in water, $\mathrm{w} / \mathrm{v})$ for $5 \mathrm{~min}$ to remove crystal calcium oxalate, rinsed in flowing water twice and oven-dried at $50^{\circ} \mathrm{C}$ for $24 \mathrm{~h}$, ground and sieved through 100 mesh-sieve, packed and stored at room temperature.

\section{Protein extraction and analysis}

Beef protein was extracted from ground beef added with phosphate buffer $\left(\mathrm{pH} 7.0,4^{\circ} \mathrm{C}\right)$ with a ratio of 1:10 according to a method described by Choi et al. [6] with modification. The mixture was then homogenized at 2,500 rpm for $2 \mathrm{~min}$. The homogenized mixture was centrifuged at 4,000 $\mathrm{xg}$ 
for $25 \mathrm{~min}$ at $4^{\circ} \mathrm{C}$, the supernatant was removed, and the pellet was stored for $24 \mathrm{~h}$ at $4^{\circ} \mathrm{C}$. The pellet was added with $\mathrm{NaCl}$ at different concentrations $(0.5 \%, 1.0 \%, 1.5 \%$, and $2.0 \%, \mathrm{w} / \mathrm{w})$ and $20 \mathrm{~mL}$ of phosphate buffer $\left(\mathrm{pH} 7.0,4^{\circ} \mathrm{C}\right)$, homogenized at 2,500 $\mathrm{rpm}$ for $2 \mathrm{~min}$, and centrifuged at $4,000 \times \mathrm{g}$ for $25 \mathrm{~min}$ at $4^{\circ} \mathrm{C}$. The supernatant was collected and stored at $4^{\circ} \mathrm{C}$ for $12 \mathrm{~h}$ prior to analysis.

The $\mathrm{pH}$ of the supernatant was measured according to Hashemi and Jafarpour [17] in duplicate using a calibrated $\mathrm{pH}$ meter. Protein concentrations of the supernatant was determined using Bradford's method and expressed as $\mu \mathrm{g} / \mathrm{mL}$ [18]. The protein fractions were separated by $1 \mathrm{D}$ sodium dodecyl sulfate polyacrylamide gel electrophoresis (SDS PAGE) as described by Sambrook and Russell [19]. The sample aliquots ( $2 \mathrm{mg} / \mathrm{mL}$ in phosphate buffer) were mixed with SDS gel loading buffer (50 mM Tris-Cl, $100 \mathrm{mM}$ dithiothreitol, 0.004\% blue bromophenol, 10\% glycerol, and 2\% SDS). The mixture was denatured at $90^{\circ} \mathrm{C}$ for $3 \mathrm{~min}$ and loaded at $10 \mu \mathrm{g}$ protein per lane onto the 10\% polyacrylamide gels (Mini PROTEAN 3, Bio-Rad, CA, USA) running in Tris-glycine buffer at $200 \mathrm{~V}$ constant voltage for $40 \mathrm{~min}$ at room temperature. Gels were stained using Coomassie Brilliant Blue R-250 followed by destaining with 40\% methanol and 7\% acetic acid in distilled water. The SDS PAGE gels were scanned and the relative molecular weight of the protein was determined using standard marker $[6,20]$.

\section{Salt-soluble protein and elephant foot yam flour gel preparation}

Salt-soluble protein and elephant foot yam flour were mixed, homogenized at 2,500 rpm for 2 min, and incubated at $20^{\circ} \mathrm{C}$ for $10 \mathrm{~min}$. The mixture was gelatinized at $90^{\circ} \mathrm{C}$ for $20 \mathrm{~min}$ and cooled down at $4^{\circ} \mathrm{C}$ for $12 \mathrm{~h}$. The $\mathrm{pH}$, gel strength, instrumental color, proximate composition, and microstructure of the gels were then analyzed.

\section{$\mathrm{pH}$ measurement}

Gel sample $(5 \mathrm{~g})$ was added with $20 \mathrm{~mL}$ of distilled water and homogenized at 2,500 rpm for 2 $\min$. The $\mathrm{pH}$ of the slurry was determined in duplicate using a calibrated $\mathrm{pH}$ meter.

\section{Gel strength analysis}

The sample was sliced into $10 \mathrm{~mm}$ thick with $25 \mathrm{~mm}$ diameter and placed on the center of the plate. The penetration force representing gel strength $(\mathrm{N})$ was measured using a texture analyzer XT plus (Stable Micro Systems, Goldaming, UK). The gels were compressed twice to 25\% of original height at a constant speed of $1.0 \mathrm{~mm} / \mathrm{s}$ using a $\mathrm{P} 35$ probe ( $35 \mathrm{~mm}$ cylinder). The pre-test and posttest speed were $1.0 \mathrm{~mm} / \mathrm{s}$ and $10 \mathrm{~mm} / \mathrm{s}$, respectively [21].

\section{Instrumental color analysis}

The instrumental surface color of the gels was recorded by measuring International Commission on Illumination's system for lightness (CIE L*), redness (CIE $\left.\mathrm{a}^{*}\right)$, and yellowness (CIE $\left.\mathrm{b}^{*}\right)$ using a chroma meter (CR-400, Konica Minolta, Tokyo, Japan). The light source of illuminant C ( $2^{\circ} \mathrm{ob}-$ server) with $8 \mathrm{~mm}$ aperture and attached-closed cone was calibrated using a white plate ( $\mathrm{Y}=93.6$, $\mathrm{X}=0.3134, \mathrm{y}=0.3194)$.

\section{Microstructure analysis}

SEM (TM3000, Hitachi High-Technologies, Tokyo, Japan) was used for the observation of the microstructure of the gels. Sample was sliced into 1-2 mm thick and fixed with $2.5 \%$ glutaraldehyde in $0.2 \mathrm{M}$ phosphate buffer ( $\mathrm{pH}$ 7.0) for $2 \mathrm{~h}$, washed and soaked in distilled water for $1 \mathrm{~h}$, and serial dehydrated with ethanol in distilled water $(50 \%, 60 \%, 70 \%, 80 \%, 90 \%$, and $100 \%$, v/v) for $1 \mathrm{~h}$ each. The dried sample was put onto holder, coated with gold, and visualized under SEM at magni- 
fication of $\times 100$ [17].

\section{Proximate composition analysis}

Moisture, crude protein, crude fat, and ash content were determined using AOAC official methods [22]. Moisture content was determined by drying the samples in an oven at $105^{\circ} \mathrm{C}$ for $24 \mathrm{~h}$. Crude fat content was determined by ether extraction using a Soxhlet system. Nitrogen content was determined using the Kjeltec system (2200 Kjeltec Auto Distillation Unit, Foss, Hillerød, Denmark). Crude protein was calculated as nitrogen content multiplied by 6.25. Ash content was determined by burning the samples in a muffle furnace at $550^{\circ} \mathrm{C}$ for $8 \mathrm{~h}$.

\section{Statistical analysis}

This study employed a randomized block design and each replication being treated as a block. In first study, the effect of salt concentration $(0.5 \%, 1.0 \%, 1.5 \%$, and $2.0 \%$, w/w) on the $\mathrm{pH}$ and salt-soluble protein concentration of beef extract was observed. One-way analysis of variance (ANOVA) was employed to determine the effect of salt concentration. In second study, two-way ANOVA was employed to determine the effect of salt concentration and the addition level of elephant foot yam flour $(5 \%, 10 \%$, and $15 \%$, w/w). Significant differences $(p<0.05)$ of mean values among treatments were determined using Duncan's multiple range test.

\section{RESULTS AND DISCUSSION}

\section{Effect of salt concentration on ph and protein solubility of beef extract}

Table 1 shows that $\mathrm{pH}$ and salt-soluble protein concentration of beef extract did not differ significantly among treatments. The $\mathrm{pH}$ of the beef extract ranged from 6.90 to 6.98 as the result of using phosphate buffer $(\mathrm{pH} 7.0)$ for extraction. Further, the $\mathrm{pH}$ of the beef used in this study was 5.96, which is relatively high for normal meat ( $\mathrm{pH} 5.5-5.6$ ) as the result of early collection (5 h post slaughter and being frozen $24 \mathrm{~h}$ ). The observed concentration of salt-soluble proteins ranged from 2.96 to 3.84 . The observed $\mathrm{pH}$ (6.90-6.98) supported the extraction of salt-soluble protein in present study.

Meat proteins, that are soluble in a solution with ionic strength more than $0.3 \mathrm{M}$, are categorized into salt-soluble (myofibrillar) protein. These proteins comprise approximately $50 \%$ to $60 \%$ of meat protein, e.g. actin and myosin [4]. Çarkcioğlu et al. [23] mentioned that myofibrillar proteins play a critical role in texture development for both raw and processed meat. Further, postmortem conditions, such as $\mathrm{pH}$ and the use of salt in processing, influence the extractability of myofibrillar protein. Eady et al. [20] reported that the solubility of protein declines when the $\mathrm{pH}$ is around its isoelectric point (5.4-5.5). The former condition ( $\mathrm{pH}$ 5.4-5.5) leads the myofibrillar proteins structure cannot be unfolded, thus limiting the extraction of actin and myosin. The addition of salt optimizes the extraction of myofibrillar proteins and eventually develop a good texture of protein gel [24].

Table 1. The effect of salt concentration on $\mathrm{pH}$ and salt-soluble protein concentration of beef extract

\begin{tabular}{ccc}
\hline Salt concentration $(\%)$ & pH & Protein concentration $(\mu \mathrm{g} / \mathrm{mL})$ \\
\hline 0.5 & $6.98 \pm 0.02$ & $2.96 \pm 0.03$ \\
1.0 & $6.96 \pm 0.11$ & $3.01 \pm 0.04$ \\
1.5 & $6.92 \pm 0.10$ & $3.55 \pm 0.04$ \\
2.0 & $6.90 \pm 0.05$ & $3.84 \pm 0.05$ \\
\hline
\end{tabular}

Data are presented as mean \pm standard deviation.

No significant effect was found. 
These suggest that salt concentration ranged from $0.5 \%$ to $2.0 \%$ showed comparable results in the extraction of myofibrillar proteins of beef with $\mathrm{pH}$ of 5.96 .

\section{Effect of salt concentration on myofibrillar protein fractions in beef extract}

The salt-soluble proteins, that were extracted from beef round using salt solution at different concentrations, are shown in Fig. 1. The bands in lane 1 to 6 were identified as myosin group as the molecular weight ranged from $68 \mathrm{kDa}$ to $240 \mathrm{kDa}$, while the bands in lane 7 were identified as actin group with molecular weight of $45 \mathrm{kDa}$. The SDS PAGE gel shows that the bands for myosin group were thicker than those of actin group. Price and Schweigert [25] mentioned that myosin group comprises approximately $55 \%$ to $60 \%$ of myofibrillar proteins. Choi et al. [6] added that myofibrillar proteins with molecular weight of $205 \mathrm{kDa}$ are classified as heavy chain myosin, while those with molecular weight of $45 \mathrm{kDa}$ are actin. In more details, the molecular weight of heavy meromyosin, light meromyosin fraction I, light meromyosin, tropomyosin, and G-actin are 232, $120,96,68$, and $47 \mathrm{kDa}$, respectively [25]. Therefore, the use of salt with concentration ranged from $0.5 \%$ to $2.0 \%$ was effective to extract myosin, the major protein group of myofibrillar proteins, and the differences in salt concentration did not show any significant effect on fragmentation pattern.

\section{Interactions between beef salt-soluble proteins and elephant foot yam flour}

Table 2 shows that salt concentration did not affect the $\mathrm{pH}$ and instrumental color of the gel made from beef salt-soluble protein and elephant foot yam flour. However, gel strength was significantly influenced by both salt concentration $(p<0.01)$ and the addition of elephant foot yam flour $(p<$ $0.01)$. On the other hand, the addition of elephant foot yam flour influenced the $\mathrm{pH}(p<0.05)$ and instrumental color of the gels $(p<0.05)$. The interaction effect was observed only for gel strength $(p$ $<0.01)$. These indicate that elephant foot yam flour showed greater impact on the characteristic of the gel than salt used for extraction.

The addition of elephant foot yam flour increased the $\mathrm{pH}$ of the gel resulting an increase of gel strength. Although there was no significant difference on $\mathrm{pH}$ found between the gels that were added with 5\% and 15\% elephant foot yam flour, the texture of the gel that made from 15\% elephant foot yam flour was significantly firmer than that made from $5 \%$ elephant foot yam flour. These suggest that the more the elephant foot yam flour was added, the higher the $\mathrm{pH}$ and the

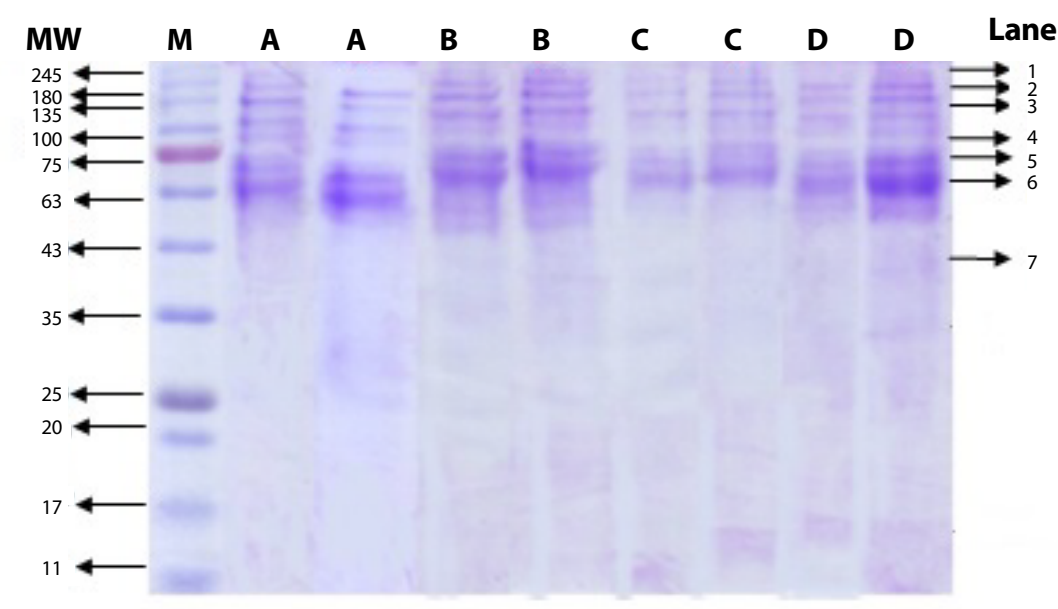

Fig. 1. SDS-PAGE of the salt-soluble protein extracted from beef round using salt at different concentrations. MW, molecular weight; $M$, standard marker; $A, 0.5 \%$ salt; $B, 1.0 \%$ salt; $C, 1.5 \%$ salt; $D, 2.0 \%$ salt. Lane 1-6 were myosin groups and lane 7 was actin group. 
Table 2. The effect of salt concentration and elephant foot yam flour on $\mathrm{pH}$, gel strength and instrumental color of the gels

\begin{tabular}{|c|c|c|c|c|c|c|}
\hline Elephant foot yam flour (\%) & Salt concentration (\%) & $\mathrm{pH}$ & Gel strength (N) & $L^{*}$ & $a^{*}$ & $\mathbf{b}^{*}$ \\
\hline \multirow[t]{4}{*}{5} & 0.5 & $6.58 \pm 0.24$ & $1.60 \pm 0.26^{a}$ & $37.43 \pm 1.36$ & $12.23 \pm 0.85$ & $12.80 \pm 1.39$ \\
\hline & 1.0 & $6.73 \pm 0.06$ & $1.37 \pm 0.76^{\mathrm{a}}$ & $40.27 \pm 0.57$ & $13.53 \pm 0.59$ & $13.43 \pm 0.74$ \\
\hline & 2.0 & $6.74 \pm 0.06$ & $2.27 \pm 0.40^{\mathrm{a}}$ & $40.47 \pm 1.98$ & $13.97 \pm 1.36$ & $13.62 \pm 1.36$ \\
\hline & Mean & $6.61 \pm 0.20^{\mathrm{a}}$ & $1.77 \pm 1.28^{\mathrm{a}}$ & $42.33 \pm 1.03^{b}$ & $15.63 \pm 1.67^{\mathrm{b}}$ & $15.63 \pm 1.67^{b}$ \\
\hline \multirow{3}{*}{10} & 1.5 & $6.69 \pm 0.05$ & $7.70 \pm 0.82^{\mathrm{bc}}$ & $41.73 \pm 1.36$ & $15.43 \pm 1.14$ & $15.07 \pm 1.29$ \\
\hline & 2.0 & $6.68 \pm 0.07$ & $7.50 \pm 0.92^{\mathrm{bc}}$ & $42.03 \pm 0.65$ & $15.30 \pm 0.26$ & $14.93 \pm 0.85$ \\
\hline & Mean & $6.68 \pm 0.18^{\mathrm{ab}}$ & $7.07 \pm 1.37^{b}$ & $41.96 \pm 1.82^{b}$ & $15.18 \pm 1.61^{\mathrm{b}}$ & $15.18 \pm 1.61^{b}$ \\
\hline \multirow[t]{2}{*}{15} & 0.5 & $6.59 \pm 0.07$ & $9.27 \pm 1.53^{c}$ & $42.80 \pm 0.95$ & $15.63 \pm 0.65$ & $16.47 \pm 1.21$ \\
\hline & Mean & $6.70 \pm 0.19^{b}$ & $11.87 \pm 1.63^{\mathrm{c}}$ & $39.59 \pm 1.75^{\mathrm{a}}$ & $13.37 \pm 1.58^{\mathrm{a}}$ & $13.37 \pm 1.58^{\mathrm{a}}$ \\
\hline
\end{tabular}

Data are presented as mean \pm standard deviation.

${ }^{\mathrm{a}-\mathrm{e}}$ Means within the same column are significantly different $(p<0.05)$.

firmer the texture of the gel were resulted. Eady et al. [20] reported that elevated $\mathrm{pH}$ in meat emulsion system affects the unfolding of meat protein, resulting an increase of water absorption. The addition of elephant foot yam flour would result in more water absorption and retention in the emulsion system. Furthermore, the gelatinization of starch and protein complex will form a swelling 3-dimensional gel with firm texture.

The interaction effect between salt concentration and the addition level of elephant foot yam flour is shown in Table 2. High salt concentration used in this study (1.5\% and 2.0\%) enhanced the strength of the gels made from $15 \%$ elephant foot yam flour. Although the amount of protein extracted in salt solutions at different concentrations was not different statistically, the concentration of protein in solutions containing salt at $1.5 \%$ and $2.0 \%$ was numerically higher than that in lower salt concentration. These suggest that more myofibrillar proteins interacted with starch from elephant foot yam flour and formed stronger gel matrix in higher salt groups. Hasemi and Jafarpour [17] mentioned that an increase of protein level in frankfurter resulted in firmer texture. The role of elephant foot yam flour in this case is critical too as this ingredient contains starch with amylopectin level of $74.66 \%$, dietary fiber of $26.87 \%$, and glucomannan of $1.02 \%$, which has functionality as a filler and supports the development of gel matrix in meat emulsion [26]. Chen et al. [27] mentioned that polysaccharide can well interact with protein in biological system including in food. That interaction will eventually determine the characteristic of the food. In this study, the mixture of elephant foot yam flour and beef salt-soluble protein would result in the good interactions between myofibrillar protein, starch, glucomannan and water that form stable gel matrix.

The micrographs revealing the microstructure of the gels made from a mixture of salt-soluble protein and elephant foot yam flour at different addition levels are shown in Fig. 2. The micrographs No. 1, 2, 3, and III show comparable and uniform microstructures in terms of pore size and gel matrix as these treatment groups used similar amount of elephant foot yam flour (15\%), regardless the differences in salt concentration used for beef protein extraction. These indicate that salt concentration used in this study did not contribute significantly to the microstructure of the gel made from salt-soluble protein and elephant foot yam flour. Meanwhile, the micrographs No. I, II, and 

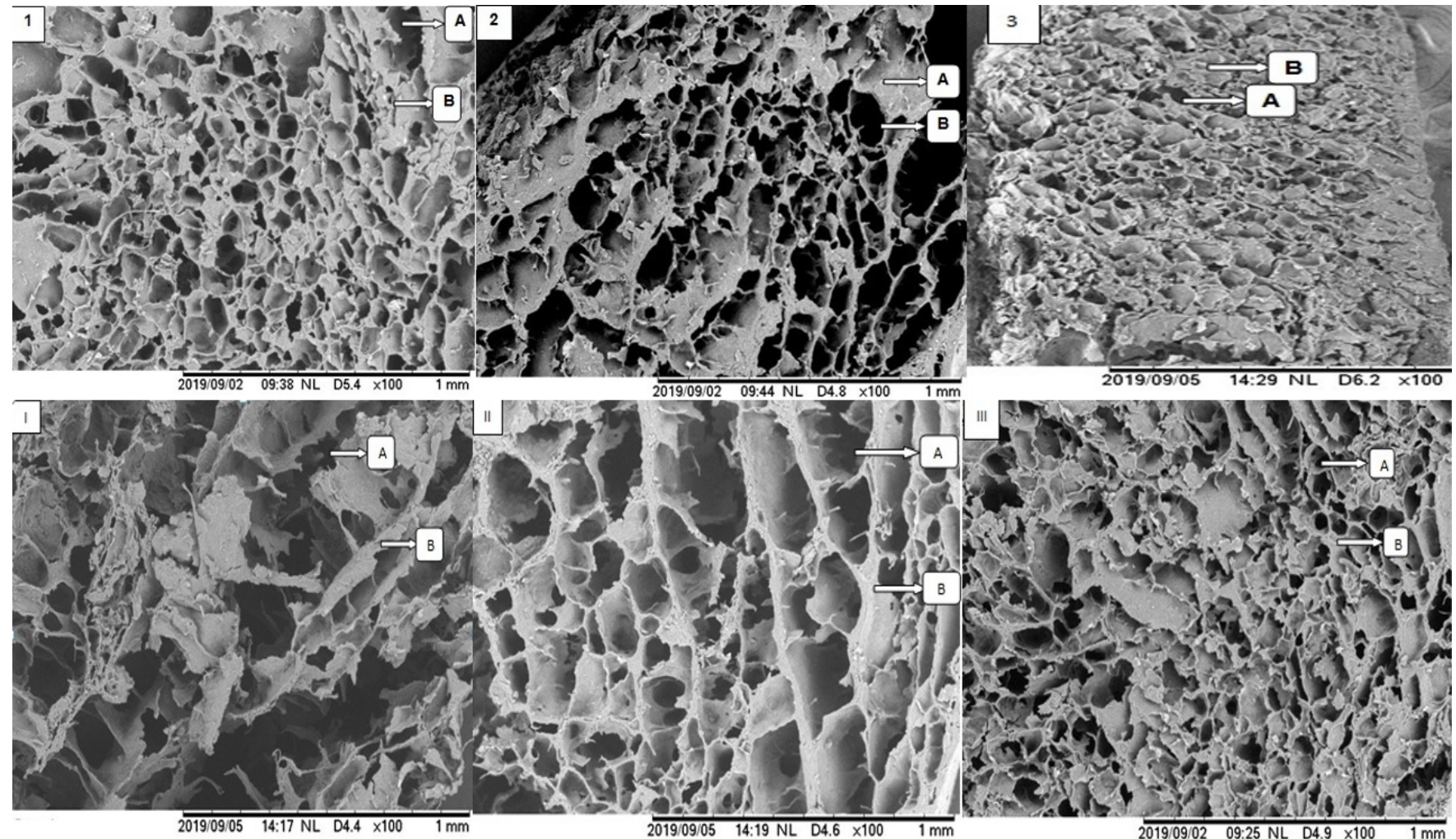

Fig. 2. The micrograph of beef salt-soluble protein and elephant foot yam flour gels visualized by scanning electron microscope. (1) Salt concentration $0.5 \%$ and elephant foot yam flour $15 \%$, (2) Salt concentration $1.0 \%$ and elephant foot yam flour $15 \%$, (3) Salt concentration $1.5 \%$ and elephant foot yam flour $15 \%$, (I) Salt concentration $2.0 \%$ and elephant foot yam flour $5 \%$, (II) Salt concentration $2.0 \%$ and elephant foot yam flour $10 \%$, (III) Salt concentration $2.0 \%$ and elephant foot yam flour $15 \%$. (A) Gel pores, (B) Gel matrix.

III show different microstructure of the gels as these gels were made from different addition levels of elephant foot yam flour with similar amount of salt (2.0\%) used for beef protein extraction. Chen et al. [27] mentioned that the differences in microstructure would be used as evidence to describe the differences in functionality of the gel matrix. The smallest pores and more uniform gel matrix were observed in micrograph III or gel made from $15 \%$ elephant foot yam flour in comparison with micrograph I and II.

The variety in size of the pores in micrograph I explains that there was a syneresis occurred during gelatinization. The syneresis was a result of weak interactions between salt-soluble protein, elephant foot yam flour and water as the addition of elephant foot yam flour was lower in this group than in other groups shown in micrograph II and III. These also suggest that the higher the addition level of elephant foot yam flour was added, the more uniform gel matrix and the smaller pores were formed in the gel. The micrograph 1,2,3, and III also explain that beef salt-soluble proteins well interact with elephant foot yam flour during gelatinization at $90^{\circ} \mathrm{C}$, when the addition level was optimized at $15 \%$. The starch from tuberous roots flour is hydrophilic and thus can absorb and retain water in the mixture during gelatinization besides binding the hydrogen bond of myofibrillar proteins [28]. Therefore, syneresis was inhibited when the addition of elephant foot yam was $15 \% \mathrm{w} / \mathrm{w}$.

The differences in salt concentration did not affect the instrumental color of the gels. However, the higher the addition level of elephant foot yam flour was, the darker the color (higher L*, a*, and $\left.b^{*}\right)$ of the gel was observed $(p<0.05)$. These results are in line with previous studies using konjac 
glucomannan, carrageenan, and alginate [13-15]. The elephant foot yam flour used in this study was originally light brown. Thus, elephant foot yam flour decreased $\mathrm{L}^{*}, \mathrm{a}^{*}$, and $\mathrm{b}^{*}$ values of the gels.

Salt concentration did not affect the moisture, crude protein, crude fat, and ash content of the gels made from beef salt-soluble proteins and elephant foot yam flour (Table 3). In contrast, the addition level of elephant foot yam contributed significantly on moisture, crude protein, and ash content. Crude fat content of the gels, however, was not affected by either salt concentration used for the extraction of myofibrillar proteins or addition level of elephant foot yam flour. The addition of elephant foot yam flour increased moisture, crude protein, and ash content of the gels $(p<0.01)$. The low proportion of moisture in 5\% group were caused by syneresis during gelatinization. Elephant foot yam flour is the source of carbohydrates such as starch and glucomannan, which are able to bound with water molecules during gel formation [29]. The crude protein, ash and carbohydrate content of the flour used in this study were $9.49 \%, 10.86 \%$, and $71.98 \%$, respectively (data are not shown). Starch and dietary fiber can replace and mimic fat in the development of meat emulsion gel matrix [30-32]. Therefore, elephant foot yam flour added the functionality of the gel as it can retain moisture and develop compact gel matrix.

\section{CONCLUSION}

Elephant foot yam flour well interacted with beef salt-soluble proteins during gelatinization to form gel and the effect was level-dependent. The use of $\mathrm{NaCl}$ for beef myofibrillar protein extraction was not level-dependent, regardless the differences in salt concentration used in current study $(0.5 \%$ $2.0 \%)$. The addition of elephant foot yam flour at $15 \%(\mathrm{w} / \mathrm{w})$ to beef protein extracted using $\mathrm{NaCl}$ at $2.0 \%(\mathrm{w} / \mathrm{w})$ could develop uniform meat emulsion gel with small pores. Therefore, elephant foot yam flour shows potency to be used in meat emulsion products as binder.

Table 3. The effect of salt concentration and elephant foot yam flour on proximate composition of the gels

\begin{tabular}{|c|c|c|c|c|c|}
\hline Elephant foot yam flour (\%) & Salt concentration $(\%)$ & Moisture (\%) & Crude protein (\%) & Crude fat (\%) & Ash (\%) \\
\hline \multirow[t]{4}{*}{5} & 0.5 & $89.72 \pm 0.93$ & $0.55 \pm 0.49$ & $0.05 \pm 0.01$ & $2.20 \pm 0.57$ \\
\hline & 1.0 & $88.18 \pm 1.98$ & $0.43 \pm 0.10$ & $0.06 \pm 0.01$ & $1.93 \pm 0.13$ \\
\hline & 2.0 & $89.28 \pm 0.14$ & $0.37 \pm 0.21$ & $0.07 \pm 0.03$ & $2.12 \pm 0.10$ \\
\hline & Mean & $76.62 \pm 1.47^{\mathrm{a}}$ & $0.45 \pm 0.58^{\mathrm{a}}$ & $0.06 \pm 0.02$ & $2.06 \pm 0.77^{\circ}$ \\
\hline \multirow{3}{*}{10} & 1.5 & $82.25 \pm 0.48$ & $0.75 \pm 0.01$ & $0.04 \pm 0.01$ & $2.29 \pm 0.15$ \\
\hline & 2.0 & $82.11 \pm 0.07$ & $0.86 \pm 0.10$ & $0.04 \pm 0.02$ & $2.42 \pm 0.15$ \\
\hline & Mean & $82.19 \pm 1.07^{b}$ & $0.73 \pm 0.61^{b}$ & $0.04 \pm 0.02$ & $2.39 \pm 0.77^{t}$ \\
\hline \multirow[t]{2}{*}{15} & 0.5 & $76.75 \pm 0.33$ & $0.92 \pm 0.19$ & $0.03 \pm 0.02$ & $2.31 \pm 0.46$ \\
\hline & Mean & $89.21 \pm 1.30^{c}$ & $0.80 \pm 0.65^{b}$ & $0.04 \pm 0.02$ & $2.58 \pm 0.83^{t}$ \\
\hline
\end{tabular}

Data are presented as mean \pm standard deviation.

${ }^{a-c}$ Means within the same column are significantly different $(p<0.05)$. 


\section{REFERENCES}

1. Liu S, Zhao P, Zhang J, Xu Q, Ding Y, Liu J. Physicochemical and functional properties of silver carp (Hypophthalmichthys molitrix) myofibrillar protein glycated with konjac oligo-glucomanan. Food Hydrocoll. 2017;67:216-23.

2. Morin LA, Temelli F, McMullen L. Interactions between meat proteins and barley (Hordeum spp.) $\beta$-glucan within a reduced-fat breakfast sausage system. Meat Sci. 2004;68:419-30.

3. Sun XD, Holley RA. Factors influencing gel formation by myofibrillar proteins in muscle foods. Compr Rev Food Sci Food Saf. 2011;10:33-51.

4. Lee SH, Joo ST, Ryu YC. Skeletal muscle fiber type and myofibrillar proteins in relation to meat quality. Meat Sci. 2010;86:166-70.

5. Lanier TC, Carvajal P, Yongsawatdigul J. Surimi gelation chemistry. In: Park JW, editor. Surimi and surimi seafood. 2nd ed. Boca Raton, FL: Taylor \& Francis; 2005. p. 435-90.

6. Choi YS, Choi JH, Han DJ, Kim HY, Lee MA, Kim HW, et al. Effects of rice bran fiber on heat-induced gel prepared with pork salt-soluble meat proteins in model system. Meat Sci. 2011;88:59-66.

7. Peng IC, Nielsen SS. Protein-protein interactions between soybean beta-conglycinin (B1-B6) and myosin.J Food Sci. 1986;51:588-90.

8. Richana N, Sunarti TC. Karakterisasi sifat fisikokimiatepung umbi dan tepung pati dari umbi ganyong, suweg, ubikelapa dan gembili.J Pascapanen. 2004;1:29-37.

9. Susilo A, Widyastuti ES, Nurvikawati YE. The quality of quail meat block on difference material and level binding.J Ilmu Teknol Has Ternak (JITEK). 2011;6:34-43.

10. Prastini AI, Widjanarko SB. Pembuatan sosis ayam menggunakan gel porang (Amorphophallus mueleri Blume) sebagai bahan pengikat terhadap karakteristik sosis. J Pangan Agroind. 2015;4:1503-11.

11. Widjanarko SB, Amalia Q, Hermanto MB, Mubarok AZ. Evaluation of the effect of yellow konjac flour- $\kappa$-carrageenan mixed gels and red koji rice extracts on the properties of restructured meat using response surface methodology.J Food Sci Technol. 2018;55:1781-8.

12. Liu J, Xu Q, Zhang J, Zhou X, Lyu F, Zhao P, et al. Preparation, composition analysis and antioxidant activities of konjac oligo-glucomannan. Carbohydr Polym. 2015;130:398-404.

13. Sato R, Katayama S, Sawabe T, Saeki H. Stability and emulsion-forming ability of water-soluble fish myofibrillar protein prepared by conjugation with alginate oligosaccharide. J Agric Food Chem. 2003;51:4376-81.

14. Chin KB, Go MY, Xiong YL. Konjac flour improved textural and water retention properties of transglutaminase-mediated, heat-induced porcine myofibrillar protein gel: effect of salt level and transglutaminase incubation. Meat Sci. 2009;81:565-72.

15. Liu L, Kerry JF, Kerry JP. Application and assessment of extruded edible casings manufactured from pectin and gelatin/sodium alginate blends for use with breakfast pork sausage. Meat Sci. 2007;75:196-202.

16. Faridah DN. Sifat fisiko-kimia tepung suweg (Amorphopallus campanulatus B1) dan indeks glikemiksnya.J Teknol Ind Pangan. 2005;8:254-9.

17. Hashemi A, Jafarpour A. Rheological and microstructural properties of beef sausage batter formulated with fish fillet mince.J Food Sci Technol. 2016;53:601-10.

18. Bradford MM. A rapid and sensitive method for the quantitation of microgram quantities of protein utilizing the principle of protein-dye binding. Anal Biochem. 1976;72:248-54.

19. Sambrook J, Russell DW. SDS-polyacrylamide gel electrophoresis of proteins [Internal]. Cold Spring Harbor Protocols. 2006 [cited 2019 Oct 17]. https://doi.org/10.1101/pdb.prot4540 
20. Eady MD, Samuel D, Bowker B. Effect of $\mathrm{pH}$ and postmortem aging on protein extraction from broiler breast muscle. Poult Sci. 2014;93:1825-33.

21. Schmiele M, Mascarenhas MCCN, da Silva Barretto AC, Pollonio MAR. Dietary fiber as fat substitute in emulsified and cooked meat model system. LWT-Food Sci Technol. 2015;61:10511.

22. AOAC [Association of Official Analytical Chemists] International. Official methods of analysis. 18th ed. Gathersburg, MD: AOAC International; 2005.

23. Çarkcioğlu E, Rosenthal AJ, Candoğan K. Rheological and textural properties of sodium reduced salt soluble myofibrillar protein gels containing sodium tri-polyphosphate. J Texture Stud. 2016;47:181-7.

24. Totosaus A, Perez-Chabela ML. Textural properties and microstructure of low-fat and sodium-reduced meat batters formulated with gellan gum and dicationic salts. LWT-Food Sci Technol. 2009;42:563-9.

25. Price JF, Schweigert BS. The science of meat and meat products. San Fransisco, CA: WH Freeman and Company; 1971.

26. Jimenez-Colmenero F, Cofrades S, Herrero AM, Solas MT, Ruiz-Capillas C. Konjac gel for use as potential fat analogue for healthier meat product development: effect of chilled and frozen storage. Food Hydrocoll. 2013;30:351-7.

27. Chen HH, Xu SY, Wang Z. Interaction between flaxseed gum and meat protein.J Food Eng. 2007;80:1051-9.

28. Ai Y, Jane LL. Gelatinization and rheological properties of starch. Starch-Stärke. 2015;67:21324.

29. Septiani D. Uji karakteristik fisik, kimia dan organoleptik pembuatan tepung umbi suweg (Amorphophalluscampanulatus B) sebagai bahan pangan alternatif.J Bioproses Komod Tropis. 2015;3:11-8.

30. Peng X, Yao Y. Carbohydrates as fat replacers. Annu Rev Food Sci Technol. 2017;8:331-51.

31. Utama DT, Jeong H, Kim J, Lee SK. Formula optimization of a perilla-canola oil $(\mathrm{o} / \mathrm{w})$ emulsion and its potential application as an animal fat replacer in meat emulsion. Korean J Food Sci Anim Resour. 2018;38:580-92.

32. Utama DT, Jeong HS, Kim J, Barido FH, Lee SK. Fatty acid composition and quality properties of chicken sausage formulated with pre-emulsified perilla-canola oil as an animal fat replacer. Poult Sci. 2019;98:3059-66. 